\title{
Serological testing in screening for adult celiac disease
}

HR Gillett, HJ Freeman. Serological testing in screening for adult celiac disease. Can J Gastroenterol 1999;13(3):265-269. Assays for celiac-related antibodies are becoming widely available, and the present review aims to clarify the use of these investigations in the diagnosis of, management of and screening for adult celiac disease. The sensitivities and specificities of various antibody tests are discussed, along with their clinical use as an adjunct to small bowel biopsy, and as a first-line investigation for patients with atypical symptoms of celiac disease or patients at high risk of developing sprue.

Key Words: Adult, Celiac disease, Endomysium, Gliadin, Reticulin, Serology

\section{Épreuve sérologique de dépistage de la sprue cœliaque}

RÉSUMÉ : Les dosages d'anticorps liés à la maladie cœliaque deviennent largement accessibles, et la présente synthèse a pour objectif de clarifier l'utilisation de ces tests pour le diagnostic, le traitement et la prise en charge de la sprue coliaque. Les sensibilités et les spécificités de plusieurs tests contenant divers anticorps sont discutées, ainsi que l'utilisation clinique de ces tests comme adjuvants à la biopsie de l'intestin grêle, et comme investigation de première ligne chez les patients accusant des symptômes atypiques de la sprue cœliaque ou chez ceux qui sont à risque élevé de la développer.

\section{Helen Rachel Gillett MD, Hugh James Freeman MD}

$\mathrm{C}$ eliac disease is a histological diagnosis, and, in patients in whom there is a clinical suspicion of the condition, small intestinal biopsy remains the first diagnostic procedure. Several assays for the detection of celiacrelated antibodies are widely available, and, although these serological tests do not replace the need for small intestinal biopsy for diagnosis, they can be extremely useful as an adjunct to diagnosis. Positive antibody tests can help guide clinicians towards biopsy in patients at high risk of developing celiac disease or in patients with a low index of suspicion for the disease. The present review aims to clarify beliefs about the role of serological tests in screening for, diagnosis of and follow-up of adult celiac disease.

The most widely used of these serological tests are assays for antigliadin antibodies (AGAs) and tissue antibodies, such as antireticulin (ARAs) and endomysium (EmAs) antibodies. AGAs are usually measured with the use of ELISA, whereas tissue antibodies are detected with the use of indirect immunofluorescence assay. Sensitivi- ties and specificities for these techniques vary widely from study to study, and comparison is made increasingly difficult by the use of different commercial kits and 'in-house' assays. Table 1 shows the sensitivities, specificities, and positive and negative predictive values of various assays. One group performed two studies using the same diffusionin-gel ELISA assay for immunoglobulin (Ig) A and IgG AGAs, and found that the combined sensitivity fell from $95 \%$ in the first study to $77 \%$ in the second $(1,2)$. The specificities of the two studies were comparable $(98 \%$ versus $95 \%)$. Another group compared two 'in-house' techniques and three commercial kits, and found that, for IgG AGAs, sensitivity varied from $69 \%$ to $91 \%$ and specificity from $2 \%$ to $59 \%$, and, for the IgA isotype AGAs, sensitivity ranged from $61 \%$ to $87 \%$ and specificity from $9 \%$ to $94 \%$ (3). Titres of AGA may also be raised in patients with atopic eczema (4), pemphigoid (5) or rheumatoid arthritis (6), and in healthy individuals (7-9).

IgA ARAs are generally detected using rodent kidney,

Division of Gastroenterology, Department of Medicine, University of British Columbia, Vancouver, British Columbia

Correspondence and reprints: Dr Helen Gillett, Gastroenterology - Room F137, University Hospital, 2211 Wesbrook Mall, Vancouver,

British Columbia V6T 1Z3. Telephone 604-822-7216, fax 604-822-7236, e-mail pgillett@interchange.ubc.ca 
TABLE 1

Sensitivities, specificities, and positive and negative predictive values of serological assays for celiac disease

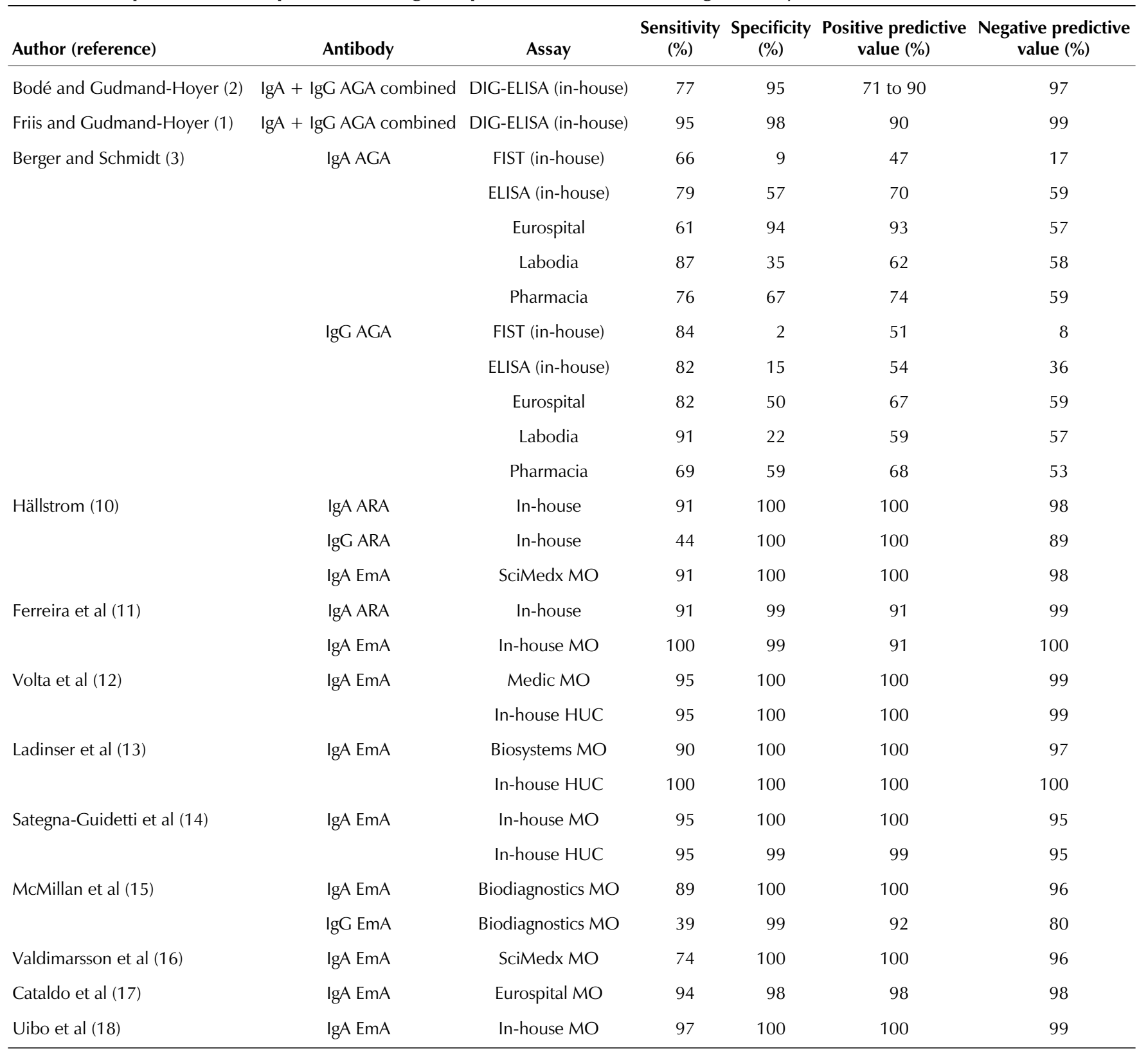

Eurospital, Trieste, Italy; Labodia, Yens, Switzerland; Kabi Pharmacia Diagnostics AB, Uppsala, Sweden; SciMedx, New Jersey; Medic, Turin, Italy; Biosystems, Genova, Italy; and Biodiagnostics, Upton upon Severn, United Kingdom. AGA Antigliadin antibody; ARA Antireticulin antibody; DIG Diffusionin-gel; EmA Endomysium antibody; FIST Fluorescent immunosorbent test; HUC Human umbilical cord; Ig Immunoglobulin; MO Monkey esophagus.

liver or stomach as the substrate. Generally, the sensitivity for celiac disease is reported to be $91 \%$, with a specificity of $99 \%$ to $100 \%(10,11)$. IgA EmAs can be detected using either monkey esophagus or human umbilical cord as the substrate. In general, published results obtained with the use of human umbilical cord by laboratories employing inhouse assays have quoted sensitivities and specificities of $95 \%$ to $100 \%$ and $99 \%$ to $100 \%$, respectively (12-14). Published results obtained with the use of commercial kits previously used monkey esophagus as the substrate, and the results obtained varied; sensitivity ranged from $74 \%$ to $95 \%$ and specificity from $98 \%$ to $100 \%(10,12,13,15$.
17). Two groups used the same kit and reported very different specificities $-74 \%$ (16) and $91 \%$ (10). The groups that used their own in-house assays tended to report better results; sensitivity ranged from $95 \%$ to $100 \%$ and specificity from $99 \%$ to $100 \%(11,14,18)$. Commercial kits using monkey esophagus are being phased out in favour of kits employing human umbilical cord, thereby reducing cost. In-house assays to detect tissue antibodies may be impractical in laboratories without pathology facilities or experience.

Although the use of AGAs alone is of limited value for identifying celiac disease in adults, it does offer some ad- 
vantages over the use of tissue antibodies. ELISAs for measuring AGAs are quantitative rather than semiquantitive, as is the indirect immunofluorescence technique, and titres generally fall quickly with dietary gluten exclusion $(19,20)$, offering noninvasive laboratory monitoring of response to treatment. EmAs disappear with treatment but may take as long as a year to do so $(10,21)$. Both antibodies can reappear with gluten challenge or relaxation of diet and, therefore, have been used to predict mucosal relapse on oral gluten challenge (22-24), but reappearance of the antibodies is often variable. In one study of Italian children, all patients not on a strict gluten-free diet or following gluten challenge were positive for $\operatorname{IgA} \mathrm{EmA}$, but not all had raised titres of IgA AGA (17).

Selective IgA deficiency (SIgAD) affects between one in 400 and one in 700 individuals (25). The prevalence of SIgAD among patients with celiac disease was reported to be as high as $2 \%$ to $3 \%(26-28)$. Because IgG AGA is often measured along with AGAs of the IgA subclass, increased titres can indicate celiac disease in the presence of SIgAD. In SIgAD patients, celiac disease would obviously be missed if IgA EmAs or ARAs were relied on to detect patients requiring biopsy. A few groups have reported the use of IgG EmA or ARA testing in these patients $(26,29,30)$, but this is not common clinical practice. It is, therefore, prudent to use a combination of $\operatorname{IgA}$ and $\operatorname{IgG}$ AGAs, and IgA EmAs or ARAs for serological testing in celiac disease. If the IgG class of AGAs is not used, then SIgAD should be excluded by measuring total serum IgA. In a large multicentre study of Italian schoolchildren, a two-step strategy was used, namely IgA and IgG AGAs were tested in the first step. Any child with IgA and/or IgG AGA positivity was recalled, and the AGA assays were repeated, along with testing for $\operatorname{IgA} \mathrm{EmA}$ and total IgA levels. Intestinal biopsy was then performed on the children with positive IgA AGA and/or IgA EmA levels, or those with raised IgG AGA titres and SIgAD (31). No similar large, multicentre studies have been performed in adults.

Small intestinal biopsy remains essential for the diagnosis of celiac disease, but, because it is now accepted that a spectrum of mucosal lesions occurs in gluten-sensitive enteropathy (32), positive celiac serology is useful as an adjunct to the diagnosis. Although patients with classical symptoms of sprue (such as chronic diarrhea or malabsorption) should undergo biopsy regardless of the results of serology, patients in whom the index of suspicion for celiac disease is low can be saved from an invasive procedure by negative serology. When IgA AGA, IgG AGA and IgA $\mathrm{EmA}$ tests are all negative, the chance of finding a flat mucosa on small bowel biopsy in an adult is approximately $2 \%$ (33). Conversely, the use of serology as a case-finding tool can lead to the diagnosis of celiac disease in patients with minor or atypical symptoms at an early point in the investigation of their symptoms. A study in Finland revealed that $37 \%$ of celiac patients diagnosed in the study period presented with minor symptoms, such as belching and tempo- rary loose stools (34). Few data are available on the cost effectiveness of serological testing in celiac disease, but one study from London, Ontario, examined this retrospectively (35). The group compared IgA EmA followed by biopsy if serology was positive with performing biopsy on all patients. The IgA EmA specificity was very poor, only $64 \%$; despite this, with the use of a cost minimization model, using serology first in patients with a low clinical suspicion of the disease was found to be less expensive than performing biopsies on all patients (35). Celiac antibodies are, however, of little value in establishing the diagnosis of dermatitis herpetiformis, despite the high probability of celiac disease in these patients. AGAs are present in only $50 \%$ of dermatitis herpetiformis patients (36), ARAs in 20\% (37) and EmAs in 70\% (38).

Because the natural history of truly silent celiac disease is not known, the use of serology testing for mass screening for celiac disease in healthy populations is not accepted $(31,39)$. Many studies have examined the prevalence of celiac disease in patients with associated conditions by using serological testing followed by small intestinal biopsy. In type I diabetes, the prevalence of celiac disease was reported to be $3.13 \%$ to $6.4 \%$ (40-42) using IgA EmA testing. Two studies found that celiac disease was associated with Down's syndrome in over $4 \%$ of patients $(43,44)$. Long term studies are yet to be performed on the outcome of treatment of celiac disease found by serology in these patients, but it is becoming increasingly accepted that patients with insulin-dependent diabetes or Down's syndrome should be tested for celiac-related antibodies and that small bowel biopsy should be performed if the antibodies are present. The frequency of testing has not been determined, but it is important to recognize that celiac disease may develop several years after diagnosis of type I diabetes (45). Another important point to note is that patients with positive tissue antibodies but normal small intestinal mucosa may have latent celiac disease; $28 \%$ of ARA-positive patients with normal jejunal mucosa developed villus atrophy on subsequent biopsy within seven years (46).

In the future, many different patient groups will be tested for celiac-related antibodies. This is likely to lead to testing for celiac disease crossing into many different medical specialities. The association between celiac disease and epilepsy has been recognized for many years (47). More recently, celiac disease was diagnosed in 24 of 31 patients with epilepsy and unexplained cerebral calcification (48), and in $16 \%$ of patients with neurological dysfunction of unknown cause (49), suggesting that patients in neurology clinics should be screened for celiac disease. A group of patients with Turner's syndrome, a condition known to be associated with autoimmune disease, were recently studied. Positive IgA EmA was found in four of 35 patients, and celiac disease was confirmed on biopsy in three of these patients (the fourth patient refused biopsy) (50), suggesting an association between these two conditions. The prevalence of celiac disease among patients with 
primary biliary cirrhosis was found to be $6 \%$ to $7 \%$ $(51,52)$. The prevalence of primary biliary cirrhosis among celiac patients was found to be $0.3 \%$ to $3 \%$ in the same studies, suggesting that mutual screening for these two conditions should be undertaken.

First-degree relatives of individuals with celiac disease have a higher prevalence of the disease $(53,54)$, and many of these individuals have few or no symptoms of the disease. Celiac serology is, therefore, useful in screening for the condition in first-degree relatives to identify which individuals should be offered a gluten-free diet in an attempt to reduce the long term risks of the disease. We stress, however, that any individual at high risk of celiac disease who has symptoms suggestive of the disease should have a small bowel biopsy performed regardless of the serology results.

In 1997, Dieterich et al (55) identified that EmAs were directed against tissue transglutaminase, enabling the development of an ELISA test for quantifying titres of this antibody. Not only will this be of great significance in the management of patients in that titres of a specific antibody for celiac can be monitored in treated patients, but this also brings researchers another step closer to unravelling the role that tissue antibodies play in the pathogenesis of celiac disease.

\section{CONCLUSIONS}

Assays for the measurement of celiac-related antibodies are widely available but are still of variable accuracy. It is, therefore, essential for clinicians to be aware of the results obtained by their local laboratories. Laboratories should be able to quote the sensitivity and specificity of their assays, and not just the manufacturer's figures if a commercial kit is used. Knowledge of external, quality-controlled results is also valuable. Clinicians should be aware of the association between SIgAD and celiac disease, and recognize that testing for IgA tissue antibodies is of no value in these patients. Testing for IgG class antibodies may be useful, but only IgG AGA tests are widely available.

Celiac serology does not replace small bowel biopsy in the diagnosis of celiac disease but is useful as an adjunct to biopsy for identifying patients in whom biopsy is appropriate, and for monitoring response to and compliance with a gluten-free diet. Testing for celiac antibodies in groups with associated conditions is becoming more widespread, and is likely to expand further as more associations are identified and if long term follow-up shows that treatment of celiac disease in these patients has a beneficial effect. Furthermore, the identification of more cases of subclinical or silent celiac disease with the use of serology will expand our knowledge of this form of the disease and the frequency of malignant and nonmalignant complications in this group of patients compared with those with classical or symptomatic disease.

\section{REFERENCES}

1. Friis SU, Gudmand-Hoyer E. Screening for coeliac disease in adults by simultaneous determination of $\operatorname{IgA}$ and $\operatorname{IgG}$ gliadin antibodies. Scand J Gastroenterol 1986;21:1058-62.

2. Bodé S, Gudmand-Hoyer E. Evaluation of the gliadin antibody test for diagnosing coeliac disease. Scand J Gastroenterol 1994;29:148-52.

3. Berger R, Schmidt G. Evaluation of six anti-gliadin antibody assays.

J Immunol Methods 1996;191:77-86.

4. Finn R, Harvey MM, Johnson PM, Verbov JL, Barnes RM. Serum IgG antibodies to gliadin and other dietary antigens in adults with atopic eczema. Clin Exp Dermatol 1985;10:222-8.

5. Kieffer M, Barnetson RS. Increased gliadin antibodies in dermatitis herpetiformis and pemphigoid. Br J Dermatol 1983;108:673-8.

6. O'Farrelly C, Marten D, Melcher D, et al. Association between villous atrophy in rheumatoid arthritis and a rheumatoid factor and gliadin-specific IgG. Lancet 1988;ii:819-22.

7. Grodzinsky E, Hed J, Lieden G, Sjogren F, Strom M. Presence of IgA and IgG AGAs in healthy adults as measured by micro-ELISA. Effect of various cutoff levels of specificity and sensitivity when diagnosing coeliac disease. Int Arch Allergy Appl Immunol 1990;92:119-23.

8. Uibo O, Uibo R, Kleimola V, Jogi T, Mäki M. Serum IgA anti-gliadin antibodies in an adult population sample. High prevalence without celiac disease. Dig Dis Sci 1993;38:2034-7.

9. Pettersson A, Sjöberg K, Lernmark A, Eriksson S. HLA genotypes in coeliac disease and healthy individuals carrying gliadin antibodies.

Eur J Gastroenterol Hepatol 1993;5:445-50.

10. Hällstrom O. Comparison of IgA-class reticulin and endomysium antibodies in coeliac disease and dermatitis herpetiformis. Gut 1989;30:1225-32.

11. Ferreira M, Lloyd-Davies S, Butler M, Scott D, Clark M, Kumar P. Endomysial antibody: is it the best screening test for coeliac disease? Gut 1992;33:1633-7.

12. Volta U, Molinaro N, De Franceschi L, Fratangelo D, Bianchi FB. IgA anti-endomysial antibodies on human umbilical cord tissue for celiac disease screening. Save both money and monkeys. Dig Dis Sci 1995;40:1902-5.

13. Ladinser B, Rossipal E, Pittschieler K. Endomysium antibodies in coeliac disease: an improved method. Gut 1994;35:776-8.

14. Sategna-Guidetti C, Grosso SB, Bruno M, Grosso S. Is human umbilical cord the most suitable substrate for the detection of endomysium antibodies in the screening and follow-up of coeliac disease? Eur J Gastroenterol Hepatol 1997;9:657-60.

15. McMillan SA, Haughton DJ, Biggart JD, Edgar JD, Porter KG, McNeill TA. Predictive value for coeliac disease of antibodies to gliadin, endomysium, and jejunum in patients attending for jejunal biopsy. Br Med J 1991;303:1163-5.

16. Valdimarsson T, Franzen L, Grodzinsky E, Skogh T, Strom M. Is small bowel biopsy necessary in adults with suspected celiac disease and IgA antiendomysium antibodies? $100 \%$ positive predictive value for celiac disease in adults. Dig Dis Sci 1996;41:83-7.

17. Cataldo F, Ventura A, Lazzari R, Balli F, Nassimbeni G, Marino V. Antiendomysium antibodies and coeliac disease: solved and unsolved questions. An Italian multicentre study. Acta Paediatr 1995;84:1125-31.

18. Uibo O, Lambrechts A, Mascart-Lemone F. Human oesophagus: a convenient antigenic substrate for the determination of anti-endomysium antibodies in the serological diagnosis of coeliac disease. Eur J Gastroenterol Hepatol 1995;7:37-40.

19. Savilahti E, Viander M, Perkkiö M, Vainio E, Kalimo K, Reunala $\mathrm{T}$. IgA antigliadin antibodies: a marker of mucosal damage in childhood coeliac disease. Lancet 1983;i:320-2.

20. Kilander AF, Nilsson LA, Gillberg R. Serum antibodies to gliadin in coeliac disease after gluten withdrawal. Scand J Gastroenterol 1987;22:29-34.

21. Mäki M, Hällstrom O, Vesikari T, Visakorpi JK. Evaluation of a serum IgA-class reticulin antibody test for the detection of childhood celiac disease. J Pediatr 1984;105:901-5.

22. Scott H, Kett K, Halstensen TS. The humoral immune system in coeliac disease. In: Marsh MN, ed. Coeliac Disease. Oxford: Blackwell Scientific Publications, 1992:239-82.

23. Kapuscinska A, Zalewski T, Chorzelski TP, et al. Disease specificity and dynamics of changes in IgA class anti-endomysial antibodies in celiac disease. J Pediatr Gastroenterol Nutr 1987;6:529-34. 
24. Mäki M, Lähdeaho ML, Hällstrom $O$, Viander M, Visakorpi JK. Postpubertal gluten challenge in coeliac disease. Arch Dis Child $1989 ; 64: 1604-7$.

25. Koisinen J. Selective IgA deficiency in blood donors. Vox Sang $1975: 29: 192-202$

26. Collin P, Mäki M, Keyriläinen $O$, Hällström $O$, Reunala $T$, Pasternak A. Selective IgA deficiency and coeliac disease. Scand J Gastroenterol 1992;27:367-71.

27. Cataldo F, Ventura A, Bottaro G, Corazza GR, Italian Society of Paediatric Gastroenterology and Hepatology (SIGEP), "Club del Tenue" Working Groups on Coeliac Disease. Prevalence and clinical features of selective immunoglobulin A deficiency in coeliac disease: an Italian multicentre study. Gut 1998;42:362-5.

28. Cataldo F, Marino V, Bottaro G, Greco P, Ventura A. Celiac disease and selective immunoglobulin A deficiency. J Pediatr 1997;131:306-8

29. Beutner EH, Kumar V, Chorzelski TP, Szaflarska-Czerwionka M. IgG endomysial antibodies in IgA deficient patient with coeliac disease. Lancet $1989 ; 1: 1261-2$. (Lett)

30. Gillett HR, Gillett PM, Kingstone K, Marshall T, Ferguson A. IgA deficiency and coeliac disease. J Pediatr Gastroenterol Nutr 1997;25:366-7. (Lett)

31. Catassi C. Screening for coeliac disease. In: Mäki M, Collin P, Visakorpi JK, eds. Coeliac Disease. Proceedings of the Seventh International Symposium on Coeliac Disease. September 5.7, 1996, Tampere, Finland. Tampere: Coeliac Disease Study Group, 1997:23-33.

32. Marsh MN, Crowe PT. Morphology of the mucosal lesion. Bailliere's Clin Gastroenterol 1995;9:273-93.

33. Bürgin-Wolff A, Hadziselimovic F. Screening test for coeliac disease. Lancet 1997;349:1843-4. (Lett)

34. Collin P, Reunala T, Mäki M. New diagnostic strategy for coeliac disease. In: Mäki M, Collin P, Visakorpi JK, eds. Coeliac Disease. Proceedings of the Seventh International Conference on Coeliac Disease September 5-7, 1996. Tampere: Coeliac Disease Study Group, 1997:47-51.

35. Atkinson K, Tokmakajian S, Watson W, Gregor J. Evaluation of the endomysial antibody for celiac disease: Operating properties and associated cost implications in clinical practice. Can J Gastroenterol 1997;11:673-7.

36. Unsworth DJ, Leonard JN, McMinn RMH, Swain AF, Holborow EJ, Fry L. Anti-gliadin antibodies and small intestinal mucosal damage in dermatitis herpetiformis. Br J Dermatol 1981;105:653-8.

37. Seah PP, Fry L, Holborow EJ, et al. Antireticulin antibody: incidence and diagnostic significance. Gut 1973;14:311-5.

38. Sulej J, Leonard JN. Anti-endomysial antibodies in dermatit is herpetiformis and coeliac disease. In: Chorzelski TP, Kumar VJ, eds. Immunopathology of the Skin. New York: Wiley, 1987:477-82.

39. Logan RF. Screening for coeliac disease - has the time come for mass screening? Acta Paediatr Suppl 1996;412:15-9.
40. Rensch MJ, Merenich JA, Lieberman M, Long BD, Davis DR, Macnally PR. Gluten-sensitive enteropathy in patients with insulin-dependent diabetes mellitus. Ann Intern Med 1996;124:564-7.

41. Sategna-Guidetti C, Grosso S, Pulitano R, Benaduce E, Dani F, Carta Q. Coeliac disease and insulin-dependent diabetes mellitus: screening in an adult population. Dig Dis Sci 1994;39:1633-7.

42. Nosari I, Casati A, Mora C, et al. The use of IgA-antiendomysial antibody test for screening coeliac disease in insulin-dependent diabetes mellitus. Diab Nutr Metab 1996;9:267-72.

43. Zubillaga P, Vitoria JC, Arrieta A, Echaniz P, Garcia-Masdevall MD. Down's syndrome and celiac disease. J Pediatr Gastroenterol Nutr 1993:16:168-71.

44. Castro M, Crino A, Papadatou B, et al. Down's syndrome and celiac disease: the prevalence of high IgA-antigliadin antibodies and HLA.DR and DQ antigens in trisomy 21. J Pediatr Gastroenterol Nutr 1993;16:265-8.

45. Mäki M, Huupponen T, Holm K, Hällstrom O. Seroconversion of reticulin autoantibodies predicts coeliac disease in insulin dependent diabetes mellitus. Gut 1995;36:239-42.

46. Volta U, Molinaro N, De Franchis R, et al. Correlation between IgA antiendomysial antibodies and subtotal villous atrophy in dermatitis herpetiformis. J Clin Gastroenterol 1992;14:298-301.

47. Chapman RG, Laidlow JM, Colin-Jones DG, Eade OE, Smith CL. Increased prevalence of epilepsy in coeliac disease. Br Med J $1978: 2: 250-1$.

48. Gobbi G, Bouquet F, Greco L, et al. Coeliac disease, epilepsy, and cerebral calcifications. The Italian Working Group on Coeliac Disease and Epilepsy. Lancet 1992;340:439-43.

49. Hadjivassiliou M, Gibson A, Davies-Jones GAB, Lobo AJ, Stephenson TJ, Milford-Ward A. Does cryptic gluten sensitivity play a part in neurological illness? Lancet 1996;347:369-71.

50. Bonamico M, Bottari M, Pasquino AM, et al. Celiac disease and Turner Syndrome. J Pediatr Gastroenterol Nutr 1998;26:496-9.

51. Kingham JGC, Parker DR. The association between primary biliary cirrhosis and coeliac disease: a study of relative prevalences. Gut $1998: 42: 120-2$

52. Bardella MT, Quatrini M, Zuin M, et al. Screening patients with celiac disease for primary biliary cirrhosis and vice versa. Am J Gastroenterol 1997;92:1524-6.

53. Vitoria JC, Arrieta A, Astigarraga I, Garcí-Masdevall D, Rodrigues-Soriano J. Use of serological markers as a screening test in family members of patients with coeliac disease. J Pediatr Gastroenterol Nutr 1994;19:304-9.

54. Mäki M, Holm K, Lipsanen V. Serological markers and HLA genes among healthy first-degree relatives of patients with coeliac disease. Lancet 1991;338:1350-3.

55. Dieterich W, Ehnis T, Bauer M, et al. Identification of tissue transglutaminase as the autoantigen of celiac disease. Nat Med $1997 ; 3: 797-801$. 


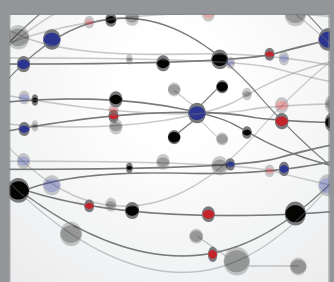

The Scientific World Journal
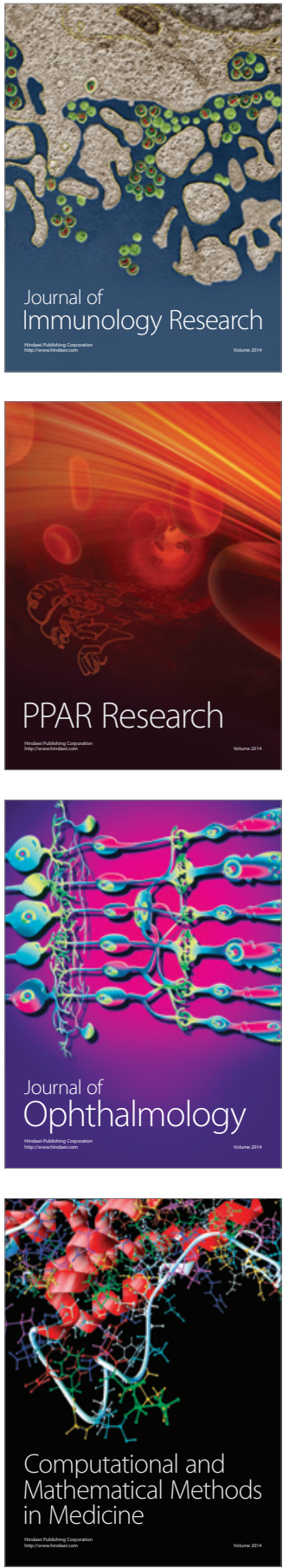

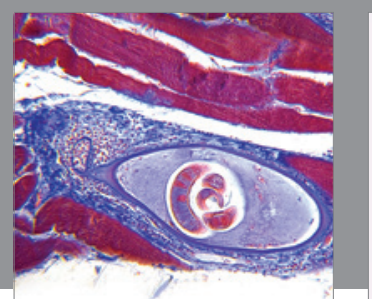

Gastroenterology Research and Practice

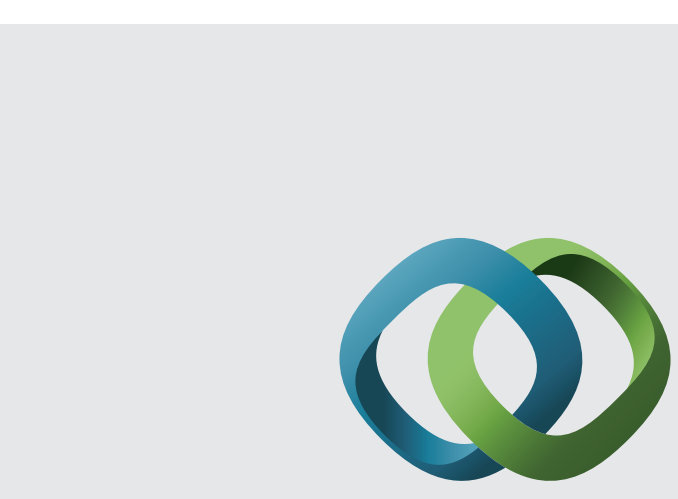

\section{Hindawi}

Submit your manuscripts at

http://www.hindawi.com
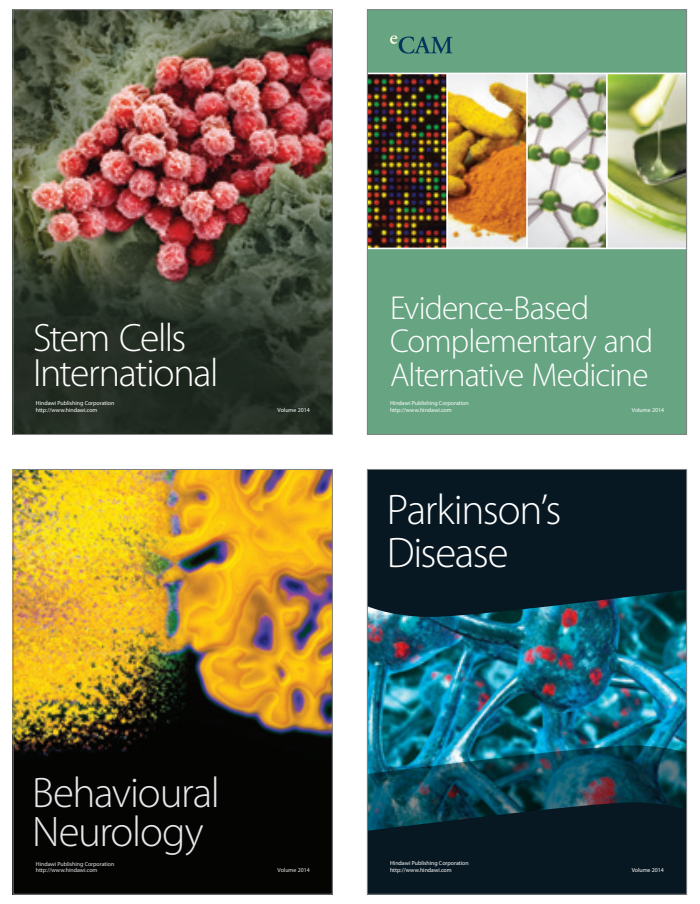
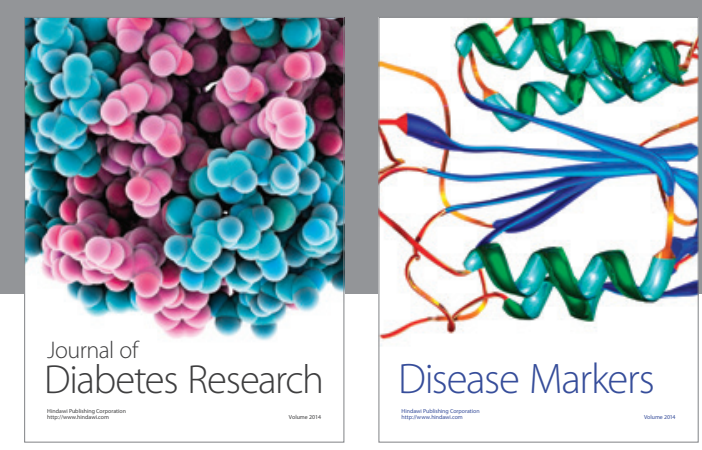

Disease Markers
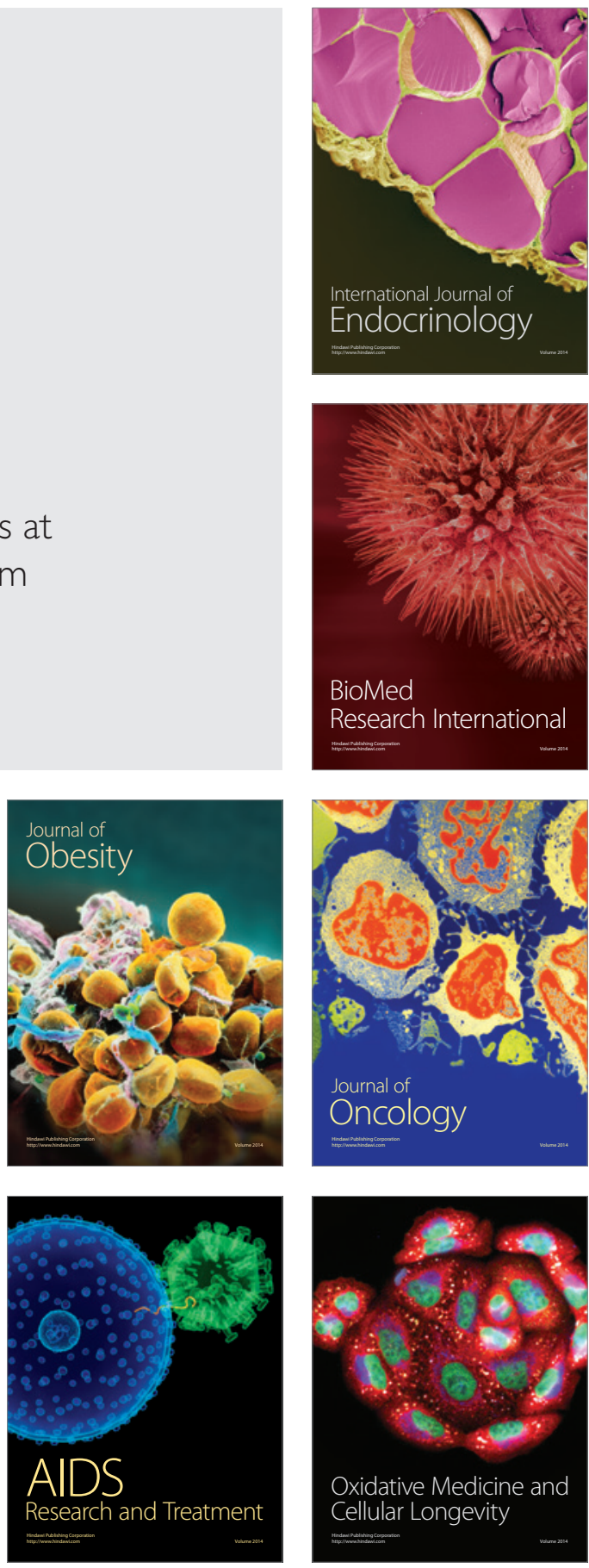